\title{
Krill excretion and its effect on primary production
}

\author{
Pascal Lehette ${ }^{1, *}$, Antonio Tovar-Sánchez ${ }^{2}$, Carlos M. Duarte ${ }^{2,3}$, \\ Santiago Hernández-León ${ }^{1}$ \\ ${ }^{1}$ Institute of Oceanography and Global Change, Universidad de Las Palmas de Gran Canaria, Spain \\ ${ }^{2}$ Department of Global Change Research, IMEDEA, CSIC-UIB, Instituto Mediterráneo de Estudios Avanzados, Esporles, \\ Mallorca, Spain \\ ${ }^{3}$ The UWA Oceans Institute, University of Western Australia, 35 Stirling Highway, Crawley, Western Australia 6009 , \\ Australia
}

\begin{abstract}
During the austral summer, zooplankton excretion along the western Antarctic Peninsula was studied in a contrasting hydrographic regime including coastal and oceanic waters. In coastal waters, ammonium supply by mesozooplankton indicated a low contribution to fuel primary production. In oceanic waters, however, Antarctic krill Euphausia superba contributed a significant percentage to the nitrogen requirements of primary producers. Thus, the ontogenetic migration of adult krill during austral summer should be a key factor regulating the regenerated ammonium for primary production. A significant coupling of ammonium concentration in the water column and in situ krill biomass supported the significant role of krill excretion in the epipelagic realm. Results from short-term experiments with E. superba indicated that ammonium excretion rates were much higher than previously found. Because the use of experimental metabolic rates that are close to field rates would be more appropriate, we suggest to re-assess the ammonium supplied by the epipelagic marine biota. Moreover, the outcomes of experimental krill excretion rates, in situ measurements of ammonium and a review of data on primary production suggest that Antarctic krill sustain a high proportion of the daily phytoplankton production.
\end{abstract}

KEY WORDS: Krill · Ammonium · Primary production - Euphausia superba - Southern Ocean · Austral summer · Western Antarctic Peninsula

\section{INTRODUCTION}

The Southern Ocean generally shows low primary production. Nevertheless, a high spatial variability in the phytoplankton biomass and production is found, especially along the Antarctic Peninsula where some regions associated with stationary phytoplankton blooms exhibit high productivity (Park et al. 1999, Varela et al. 2002, Garibotti et al. 2003). Light limitation (Dortch 1990), the low affinity of phytoplankton for nitrate owing to the low temperature (Reay et al. 1999) and the higher energetic cost of nitrate uptake compared with ammonium uptake (Dugdale 1976) or iron limitation (Martin \& Fitzwater 1988) have been proposed to explain the low productivity of the
Southern Ocean. Low iron availability can be drawn upon as a limiting factor for primary production (Timmermans et al. 1994, De Baar et al. 1995, Boyd et al. 2000, Holm-Hansen et al. 2005). However, as coastal waters, particularly along the Antarctic Peninsula, are probably iron-replete (Martin et al. 1990, Sullivan et al. 1993, Moore \& Abbott 2000, Varela et al. 2002), critical concentrations of ammonium may be a potential limiting factor as phytoplankton production is mainly sustained by this nutrient (Priddle et al. 1997, Whitehouse et al. 1999, Atkinson et al. 2001, Reay et al. 2001, Bode et al. 2002). Indeed, mesocosm experiments in Antarctic waters showed that ammonium additions greatly stimulated phytoplankton growth and biomass (Agustí et al. 2009). 
Nitrate and ammonium are important for primary production but ammonium can be a preferred source of nitrogen (Dugdale \& Goering 1967, McCarthy et al. 1977). Bacterial recycling and zooplankton excretion are critical sources of ammonium for phytoplankton growth. While nitrate commonly dominates nitrogen concentrations in Antarctic waters (Priddle et al. 1997, Bode et al. 2002), ammonium excreted by zooplankton is thought to be important for primary production (Priddle et al. 1997, Alcaraz et al. 1998, Hernández-León et al. 2008), and in fact, at least 50 to $93 \%$ of the nitrogen is assimilated as ammonium in continental shelf waters (Koike et al. 1986).

Ammonium is the principal form of dissolved nitrogen excreted by planktonic crustaceans (Båmstedt 1985, Miller \& Glibert 1998, Conover \& Gustavson 1999). Therefore, zooplankton should control primary production through both grazing and excretion. Swarms of Antarctic krill Euphausia superba represent important sources of ammonium (Atkinson \& Whitehouse 2000) since large nitrogen concentrations were found within the aggregation (Johnson et al. 1984, as cited in Priddle et al. 1997). Swarm-forming krill should cause a temporary depletion of both copepods and phytoplankton through grazing and predation but at the same time should induce optimal phytoplankton bloom-forming conditions through the release of ammonium (Tovar-Sánchez et al. 2007). Resolving krill excretion rates is, therefore, critical to estimate the contribution of ammonium to the nitrogen demand for Antarctic phytoplankton growth. Here, we try to quantify the contribution of krill ammonium excretion in the different hydrographical zones of the western Antarctic Peninsula in order to assess the role of krill in ammonium regeneration in these waters.

\section{MATERIALS AND METHODS}

\section{Sampling and data processing}

A survey along the western Antarctic Peninsula (WAP) region was conducted during the ICEPOS 2005 cruise (January to February) on board RV 'Hespérides'. Three regions with distinct hydrographic regimes were sampled along the WAP: Bellinghausen Sea (Stns Be2, Be3, Be4, Be5), Bransfield Strait (Br12, Br14, Br18) and the Antarctic Sound (As11), see (Fig. 1). Sampling was conducted during daytime for all stations (Table 1). Zooplankton was collected with a BIONESS net (Sameoto et al. 1980) equipped with 6 nets of $200 \mu \mathrm{m}$ mesh size, and the samples were used for biomass estimation. Oblique hauls started at $400 \mathrm{~m}$ depth, or within $50 \mathrm{~m}$ from the bottom for shallower stations, to the surface $(10 \mathrm{~m}$ depth). The water volume filtered by the nets was determined with a calibrated flowmeter (General Oceanics) and varied between 601 and $1524 \mathrm{~m}^{-3}$.

Zooplankton was preserved in buffered $4 \%$ formaldehyde solution just after collection, size-fractionated, counted by using a standard digital camera with a charge-coupled device (CCD) sensor (see Lehette \& Hernández-León 2009 for details) and sorted into 5 taxonomic categories. Adopted resolutions (14.7 $\mu \mathrm{m}$ pixel size for copepods and larval krill, and $33.3 \mu \mathrm{m}$ pixel size for salps and small and large euphausiids) were suitable for morphometric measurements and for semiautomated plankton recognition and classification. Image processing and machine-learning methods followed those described by Grosjean et al. (2004).

\section{Ammonium experiments}

Ammonium experiments were conducted on fresh specimens of Antarctic krill captured in oblique hauls with an Isaac-Kidd mid-water trawl (IKMT) net equipped with a mesh size of $1 \mathrm{~cm}$. The net was towed from $100 \mathrm{~m}$ depth to the surface at a speed of 2 to 3 knots during the night. All individuals captured

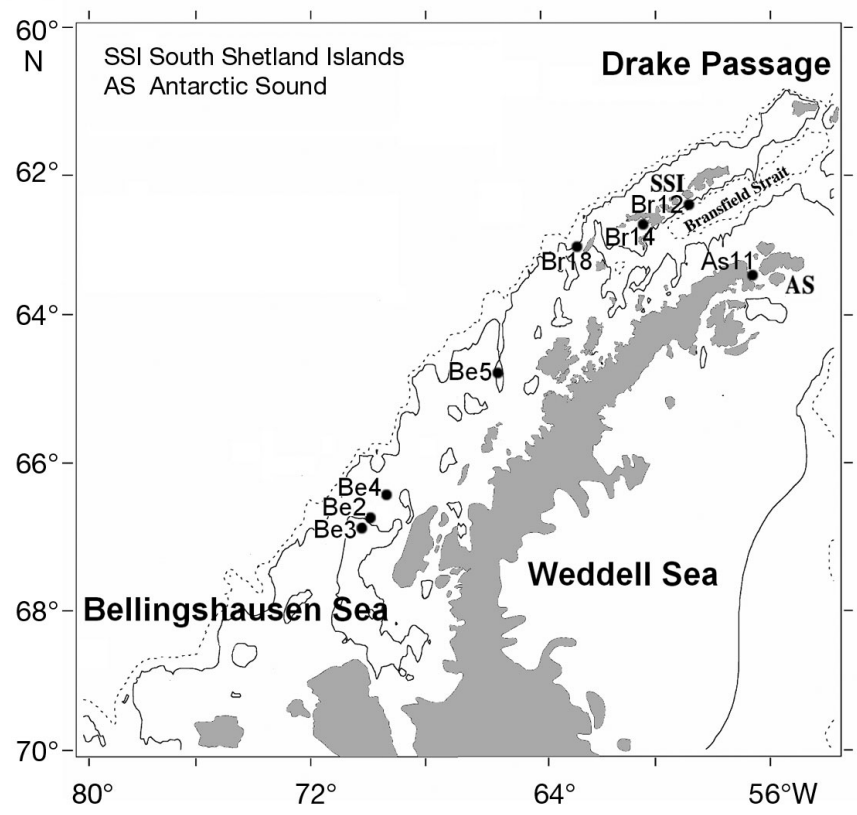

Fig. 1. Stations along the western Antarctic Peninsula which were sampled during the ICEPOS 2005 cruise. Depth contours: solid $=500 \mathrm{~m}$, dashed $=1000 \mathrm{~m}$ 
Table 1. BIONESS sampling dates, local time, geographic position, depth and category along the Antarctic Peninsula during austral summer 2005. See Fig. 1 for location of stations

\begin{tabular}{|c|c|c|c|c|c|c|}
\hline Station & $\begin{array}{l}\text { Sampling date } \\
\text { (dd/mm/yy) }\end{array}$ & $\begin{array}{l}\text { Local time } \\
(\mathrm{GMT}-3 \mathrm{~h})\end{array}$ & $\begin{array}{l}\text { Latitude } \\
\text { (S) }\end{array}$ & $\begin{array}{l}\text { Longitude } \\
\text { (W) }\end{array}$ & $\begin{array}{l}\text { Bottom } \\
\text { depth (m) }\end{array}$ & Category \\
\hline $\mathrm{Be} 2$ & 03/02/2005 & $14: 41 \mathrm{~h}$ & $66^{\circ} 34.14$ & $69^{\circ} 59.27$ & 436 & Midshelf \\
\hline $\mathrm{Be} 3$ & 04/02/2005 & $14: 48 \mathrm{~h}$ & $66^{\circ} 37.28$ & $70^{\circ} 09.31$ & 464 & Midshelf \\
\hline $\mathrm{Be} 4$ & 05/02/2005 & $14: 22 \mathrm{~h}$ & $66^{\circ} 10.65$ & $69^{\circ} 17.64$ & 340 & Midshelf \\
\hline Be5 & 06/02/2005 & $13: 06 \mathrm{~h}$ & $64^{\circ} 45.39$ & $65^{\circ} 42.27$ & 387 & Midshelf \\
\hline As11 & $11 / 02 / 2005$ & $18: 17 \mathrm{~h}$ & $63^{\circ} 23.73$ & $56^{\circ} 44.33$ & 289 & Coastal \\
\hline Br12 & $12 / 02 / 2005$ & $15: 38 \mathrm{~h}$ & $62^{\circ} 24.87$ & $58^{\circ} 48.56$ & 1222 & Coastal \\
\hline Br14 & $14 / 02 / 2005$ & $12: 47 \mathrm{~h}$ & $62^{\circ} 44.35$ & $60^{\circ} 32.27$ & 298 & Coastal \\
\hline Br18 & $22 / 02 / 2005$ & $16: 23 \mathrm{~h}$ & $63^{\circ} 00.73$ & $62^{\circ} 55.91$ & 629 & Coastal \\
\hline
\end{tabular}

were immediately transferred into on-deck aquaria with constantly renewed surface seawater. All the experiments were derived from the 'water-bottle' method (Omori \& Ikeda 1984) by using 1 or 2 individuals per flask.

Two series of experiments were carried out in filtered seawater and designed to have a significant response between the control and the experiment. For each experiment, 3 controls were done with 1 or 2 individuals per flask depending on the incubation time, i.e. 2 specimens per flask for the short incubations and 1 for the longer ones. The first series of experiments was carried out with surface seawater pumped through acid-cleaned Teflon tubing coupled to C-flex tubing (for the Cole-Parmer peristaltic pump head), filtered through an acid-cleaned polypropylene cartridge filter $(0.22 \mu \mathrm{m}$, Calyx, Micron Separations ) and collected in 21 low density polyethylene (LDPE) bottles for experiments. Experimental and control bottles were incubated in the dark in an incubation chamber set at surface water ambient temperature $\left( \pm 1^{\circ} \mathrm{C}\right)$. In a class-100 high efficiency particulate air (HEPA) hood, water samples from the experimental bottles were collected at $2 \mathrm{~h}$ intervals, from $1 \mathrm{~h}$ up to $11 \mathrm{~h}$ from the onset of each experiment. At the end of the experiments, specimens were dried to constant weight in a drying oven set at $60^{\circ} \mathrm{C}$ and weighed to the nearest mg.

The second series was performed in filtered seawater using GF/F filters (Whatman) in 21 bell-jar incubation bottles held in a thermostatic bath at $1 \pm 0.1^{\circ} \mathrm{C}$ in dim light for 1 to $7 \mathrm{~d}$. At the end of the incubation, excretion rates were calculated from differences in ammonium concentration between the control and experimental bottles. The health condition of all individuals was checked at the end of the experiment and krill individuals were then image-processed for dry weight (DW) determination (Lehette \& Hernández-León 2009).

\section{Determination of ammonium by fluorometry}

Ammonium determination based on the reaction with orthophtaldialdehyde (OPA) and sulphite followed the procedure and recommendations described by Kerouel \& Aminot (1997). Incubations of 50 min were made in PVC flasks in a thermostatic bath fixed at $37 \pm 0.1^{\circ} \mathrm{C}$. The solution was then exposed to an excitation wavelength of $365 \mathrm{~nm}$, which produced a fluorescent isoindole fluorophore detected at a specific wavelength of $425 \mathrm{~nm}$ by the spectrofluorometer (Shimadzu RF-5301 PC). After calibration, final concentration is calculated from the difference between the sample and the blank readings (milli-Q water). This automated analysis method is easy to use and highly acurate $(<0.5$ nanomolar) for ammonium determination of discrete marine samples (Kerouel \& Aminot 1997).

\section{RESULTS}

Zooplankton biomass showed sharp differences in its vertical distribution between the different regions of the WAP (Fig. 2). In the Bellingshausen Sea, the high zooplankton biomass was mainly related to large specimens of krill in the surface layer (Fig. 2A). Salps were abundant in the Bransfield Strait (Fig. 2B) with a biomass peak in the 70 to $100 \mathrm{~m}$ depth layer. In the Antarctic Sound (Fig. 2C), copepods and larval krill dominated the upper $100 \mathrm{~m}$ depth layer.

A coupling between the overall biomass of zooplankton in the water column and the in situ ammonium concentration was observed $\left(r^{2}=0.72\right.$, Fig. 3A) with a slightly better coefficient of determination for the relationship of ammonium concentration to krill biomass $\left(r^{2}=0.78\right.$, Fig. 3B).

As expected, the compilation of our experimental krill ammonium excretion rates with the results of 


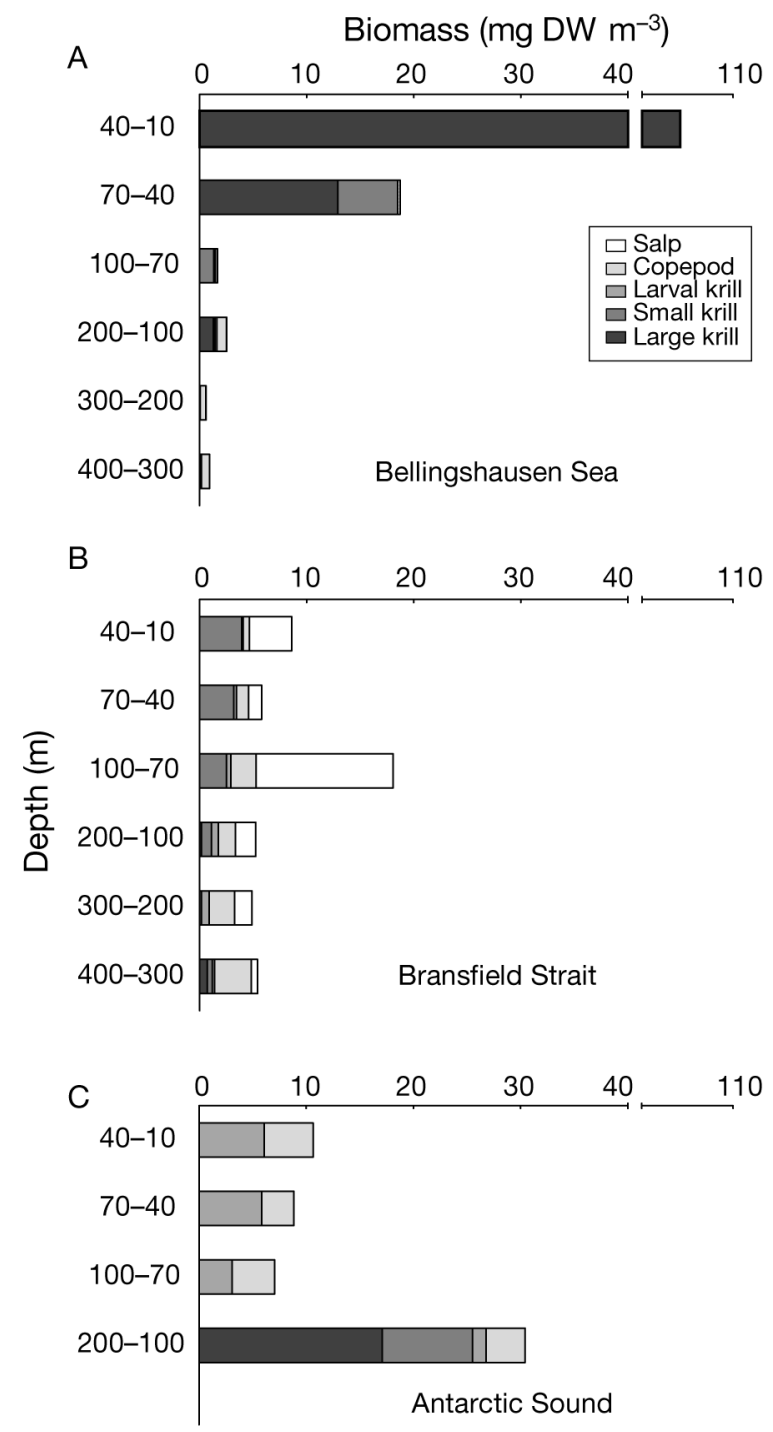

Fig. 2. Vertical distribution of the 5 dominant groups of zoo-

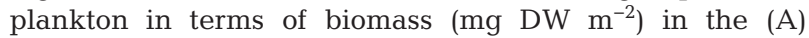
Bellingshausen Sea, (B) Bransfield Strait and (C) Antarctic Sound. DW = dry weight

Huntley \& Nordhausen (1995) and those of Atkinson \& Whitehouse (2000) indicated a decreasing krill excretion rate with the length of incubation (Fig. 4). Maximum rates $\left(30.0 \pm 6.3 \mathrm{nmol} \mathrm{NH}_{4}{ }^{+} \mathrm{mg}^{-1} \mathrm{DW} \mathrm{h}^{-1}\right.$, mean $\pm \mathrm{SD}$ ) were measured during the first hour of incubation and were $\sim 12$-fold higher than standard rates measured after $24 \mathrm{~h}\left(2.45 \pm 1.1 \mathrm{nmol} \mathrm{NH}_{4}{ }^{+} \mathrm{mg}^{-1}\right.$ DW $\left.\mathrm{h}^{-1}\right)$. The relationship between incubation time (h) and excretion rates was given by the expression:

$$
\begin{gathered}
\mathrm{NH}_{4} \text { excretion }\left(\mathrm{nmol} \mathrm{NH}_{4}{ }^{+} \mathrm{mg}^{-1} \mathrm{~h}^{-1}\right)=17.04 \mathrm{~h}^{-0.49}, \\
\mathrm{r}^{2}=0.76
\end{gathered}
$$

Combining the biomass of the main zooplankton groups with the excretion rates for each sampling

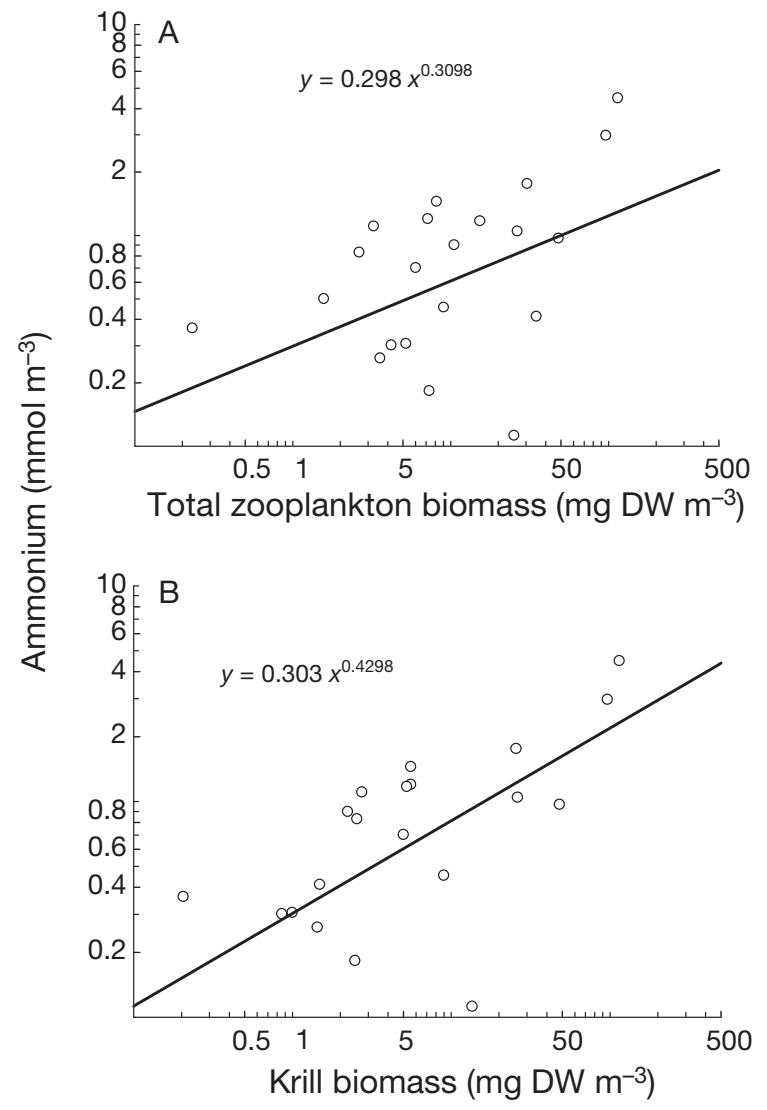

Fig. 3. Relationship between ammonium concentrations $\left(\mathrm{mmol} \mathrm{m}^{-3}\right)$ and (A) total zooplankton biomass $\left(\mathrm{mg} \mathrm{DW} \mathrm{m}^{-3}\right.$ ) $\left(\mathrm{r}^{2}=0.72, \mathrm{n}=24\right)$ and (B) krill biomass $\left(\mathrm{mg} \mathrm{DW} \mathrm{m}^{-3}\right)\left(\mathrm{r}^{2}=\right.$ $0.78, \mathrm{n}=24)$. Values from field measurements are plotted on a log-log scale. DW = dry weight

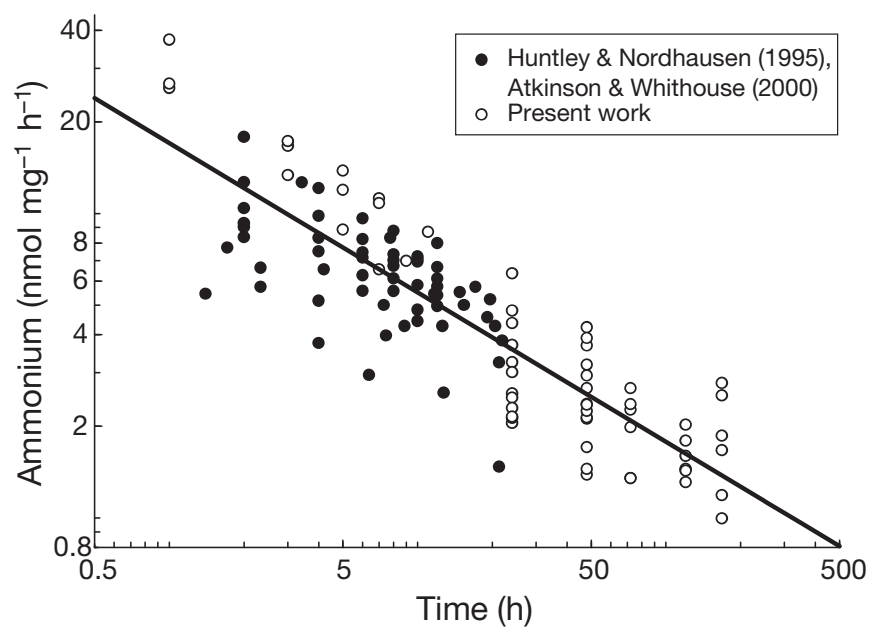

Fig. 4. Euphausia superba. Experimental krill ammonium excretion rates including data of Atkinson \& Whitehouse (2000) and Huntley \& Nordhausen (1995). Data are plotted on a log-log scale. The relationship between excretion rates and time of incubation $\left(\mathrm{r}^{2}=0.76 \mathrm{n}=117\right)$ is given by the equation: $\mathrm{nmol} \mathrm{NH}{ }_{4}^{+} \mathrm{mg}^{-1} \mathrm{~h}^{-1}=17.042 \mathrm{~h}^{-0.4906}$ 

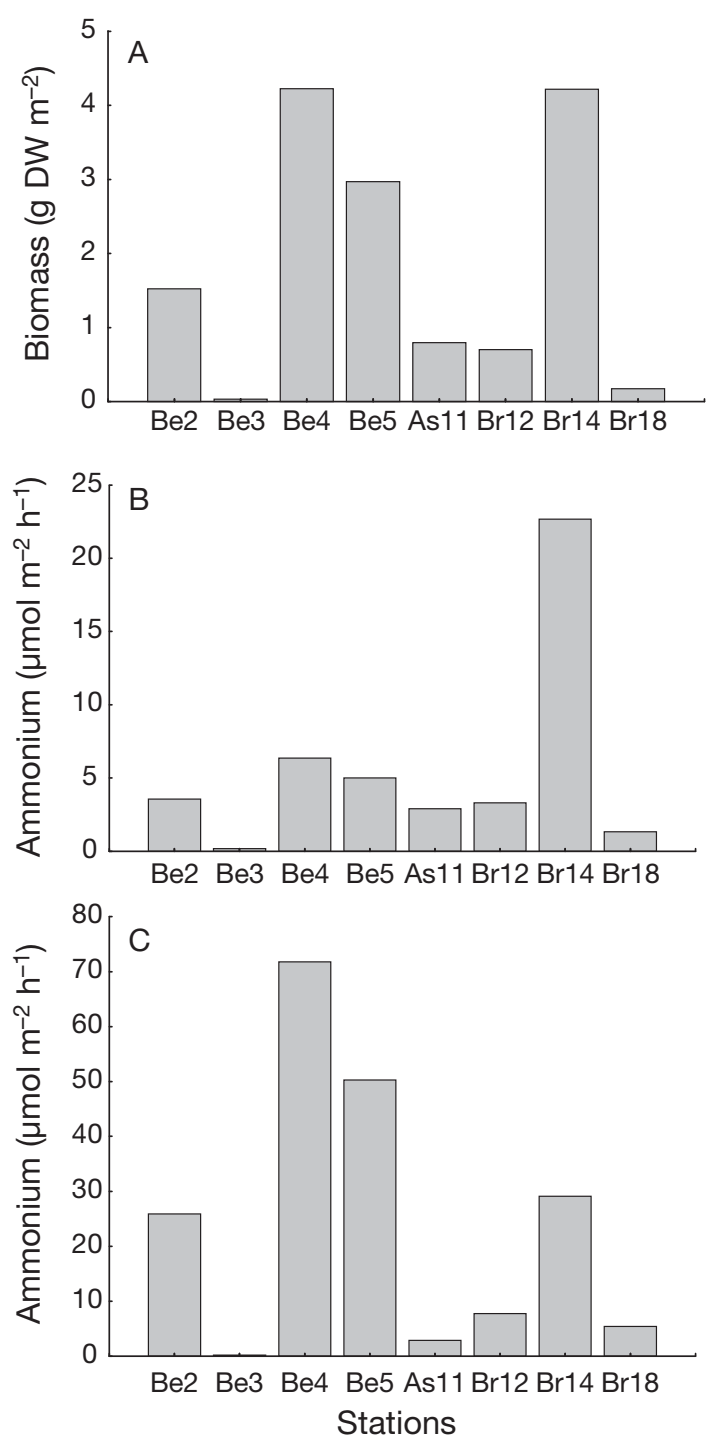

Fig. 5. (A) Total zooplanktonic biomass $\left(\mathrm{g} \mathrm{DW} \mathrm{m}^{-2}\right)$ in the upper $100 \mathrm{~m}$ layer. Total ammonia excretion rates $\left(\mu \mathrm{mol} \mathrm{m} \mathrm{m}^{-2}\right.$ $\mathrm{h}^{-1}$ ) by zooplankton in the upper $100 \mathrm{~m}$ layer (B) determined from literature data and (C) using experimental rates by small and large krill and data from literature for other taxa (salps and copepods). Note the difference in the excretion rates for Bellingshausen sector. For details on stations see Table 1 . DW = dry weight

station (Fig. 5A) (Table 2) indicated that the Bellingshausen stations exhibited rather low ammonium production rates (Fig. 5B). In contrast, salps in the Bransfield Strait provided high ammonium excretion rates in the top $100 \mathrm{~m}$ depth layer. Applying the experimental excretion rates of krill during the first

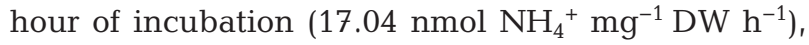
krill in the Bellingshausen Sea (Sites Be2, Be4 and Be5, see Fig. 1) exhibited much higher ammonia excretion rates than those in the other locations sampled (Fig. 5C).

\section{DISCUSSION}

Krill excretion rates measured shortly after capture were relatively high compared with published excretion rates (Hirche 1983, Huntley \& Nordhausen 1995, Hernández-León et al. 1999, Atkinson \& Whitehouse 2000). In the absence of food, Euphausia superba has proven its resilience to starvation for $>200 \mathrm{~d}$ (Ikeda \& Dixon 1984) by not only adopting strategies of moulting, cannibalism and shrinking in size (Ikeda \& Mitchell 1982), but also by reducing its excretion rates to extremely low levels (Hirche 1983, George \& Fields 1984, Atkinson \& Whitehouse 2000). The metabolism of freshly caught krill may be 2 to 4 times higher than that of starved and inactive animals (Chekunova \& Rynkova 1974, Sameoto 1976, Ikeda \& Dixon 1984). As the effect of starvation during incubations is rather fast (Le Borgne 1979, Head et al. 1988, Lehette \& Hernández-León 2010), experiments performed for long periods $(>6 \mathrm{~h}$ ) underestimate metabolic activity (Head et al. 1988), which accounts for the low excretion rates previously observed when long incubation times were used. The exponential decline in excretion rates with incubation time is clearly observed in our experiment (see Fig. 4) and is consistent with that reported in the literature (see Atkinson \& Whitehouse 2001, Tovar-Sanchez et al. 2007, Lehette \& Hernández-León 2010). Lehette \& Hernández-León (2010) observed a factorial scope (ratio between active metabolism and standard metabolism) of 11 for subtropical copepods, which is similar to the short-term excretion rates of $\sim 12$ in krill obtained after capture and observed in the present work. Short-term incubation periods yielding higher metabolic rates are appropriate given the continuous feeding habit of krill and would be most suitable to represent in situ metabolic rates of zooplankton (Satomi \& Pomeroy 1965, Webb \& Johannes 1967, Biggs 1977, Le Borgne 1979, Omori \& Ikeda 1984, Båmstedt 1985). However, high metabolic rates in experiments without acclimation periods could be due to an effect of stress after capture. In that regard, Ikeda \& Skjoldal (1980) found that this decline in metabolic rates is due to the effect of food shortage during incubation rather than to the effect of stress after capture. Thus, immediate measurement after the catch is thought to be a more realistic approach to assess field rates (Ikeda et al. 2000), and should also minimize the environmental condition, nutritional status and starvation effect on metabolic rates. Therefore, using this short-term assessment of excretion, rates were expected to be in the upper range of published krill excretion rates in the WAP region during 
Table 2. Ammonia excretion rates of the dominant groups of zooplankton as compliled from the literature and experimental results of this study

\begin{tabular}{|c|c|c|c|}
\hline Group & Dry weight range & $\begin{array}{c}\text { Excretion rates } \\
\left(\mathrm{nmol} \mathrm{NH}{ }_{4}^{+} \text {ind. }^{-1} \mathrm{~h}^{-1}\right)\end{array}$ & Source \\
\hline Salps & $10.6-14.4 \mathrm{mg}$ & $59.78-80.23$ & Alcaraz et al. (1998) \\
\hline Copepods & $1.9-138.1 \mu \mathrm{g}$ & $0.33-0.74$ & Ikeda et al. $(2001)^{\mathrm{a}}$ \\
\hline Larval krill & $233.3-544.6 \mu \mathrm{g}$ & $1.94-4.54$ & Meyer et al. $(2002)^{b}$ \\
\hline Small krill & $3.6-27.9 \mathrm{mg}$ & $11.65-59.85$ & Atkinson \& Whitehouse (2000) \\
\hline Large krill & $104.7-186.3 \mathrm{mg}$ & $172.16-272.83$ & Atkinson \& Whitehouse (2000) \\
\hline Small and large krill & $3.6-186.3 \mathrm{mg}$ & $61.34-475.42$ & Present study ${ }^{\mathrm{C}}$ \\
\hline
\end{tabular}

winter $\left(>15 \mathrm{nmol} \mathrm{NH}_{4}{ }^{+} \mathrm{mg}^{-1} \mathrm{DW} \mathrm{h}^{-1}\right.$; George \& Fields 1984, Huntley \& Nordhausen 1995). In this sense, metabolic rates by polar invertebrates in summer are supposed to reflect maximal annual metabolic rates (Clarke \& Prothero-Thomas 1997).

The tight coupling between in situ ammonium measurements and krill biomass is consistent with our independent calculations pointing to a prevalence of krill contributions compared with those of other groups (Fig. 3B). For instance, Atkinson et al. (2001) suggested that copepods and krill excretion can supply up to $80 \%$ of the ammonium required for primary production and that this was related to the abundance of krill. Priddle et al. (1997) drew similar conclusions but also pointed out the importance of krill at low densities that could sustain elevated ammonium concentrations in near-surface waters. Recently, Whitehouse et al. (2011) also confirmed similar evidence of enhanced in situ ammonium concentration at higher krill densities. The uncertainties of their krill acoustic detection and their underestimation of excretion rates (Whitehouse et al. 2011) should explain the slight discrepancies with our data. Accurate estimates of zooplankton abundance and biomass still remain a challenge since a large variability occurs between net and acoustic methods or even within net sampling (Burd \& Thomson 2012). Thus, optical devices could be integrated with net samplers to increase both accuracy and efficiency of plankton surveys (Broughton \& Lough 2006).

The rather robust potential relationship between krill biomass and in situ ammonium concentration could confirm the importance of krill excretion at higher densities. Under conditions of high food availability, krill aggregation is expected to be higher (Daly \& Macaulay 1991) and should directly affect local nutrient concentration in the surrounding waters. The importance of the swarming behaviour of Antarctic krill to fuel primary production should also be considered. Indeed, Antarctic krill are generally found in aggregations at depth during daytime mostly to avoid predation (Ritz et al. 2003), dispersing in the upper layer to feed during the night period (Kalinowski 1978, Tomo 1983, as cited in Zhou \& Dorland 2004). Nevertheless, this pattern may change owing to physical and biological constraints (Zhou \& Huntley 1996, Zhou \& Dorland 2004). It seems that krill living solitarily are likely to be stressed, and they will respond to neighbouring individuals by decreasing their metabolic rate and saving energy (Ritz 2000, Ritz et al. 2001). Aggregation behavior is believed to confer lower predation risk (O'Brien 1987, Ritz 2000), to reduce energy expenditure of hydrodynamic processes (Ritz 2000) but also to lower food intake owing to intraspecific competition (Morris et al. 1983, Ritz 2000). Thus, the behaviour of swarm-forming krill should probably affect their metabolic activity by lowering it. Some observations showed that krill swarms can alter the structure of zooplankton communities, decreasing copepod abundance, but also other zooplankton taxa (Nordhausen 1994, Atkinson et al. 1999, Priddle et al. 2003). Hence, the high in situ ammonium concentration at high krill biomass (see Fig. 3B) is in agreement with the carnivorous feeding of krill on N-rich copepods (Granéli et al. 1993).

Thus, in order to determine in situ ammonia excretion rates of krill and because zooplankton metabolism in the field is never maximal (Hernández-León \& Ikeda 2005), we suggest that field excretion rates be represented by those calculated after $1 \mathrm{~h}$ of incubation (i.e. 10 to $30 \mathrm{nmol} \mathrm{NH}_{4}{ }^{+} \mathrm{mg}^{-1} \mathrm{DW} \mathrm{h}^{-1}$, Fig. 4). By applying those rates to observed krill biomass, oceanic waters off the Bellingshausen Sea were observed to have supported much higher ammonium production rates (Fig. 5B,C) than did waters of the Bransfield Strait region. During the transition from bloom to post-bloom conditions, small krill inhabit 
coastal waters (Siegel 2005) as observed in the Bransfield Strait and Antarctic Sound, whereas larger specimens inhabit the open waters of the Bellingshausen Sea (Fig. 2A). The high ammonium concentration found in 10 to $40 \mathrm{~m}$ depth of the Bellingshausen Sea (up to $4.5 \mathrm{mmol} \mathrm{m}^{-3}$, data not shown) was closely linked to the high krill biomass (Fig. 2A). Thus, large krill performing their ontogenetic migration offshore (Siegel 1988) and preying upon large copepods (Hernández-León et al. 2001, 2008) probably have an important role in nutrient regeneration (Atkinson et al. 2001).

We also proposed to estimate the contribution of ammonium produced by the main taxonomic groups to primary production in the top $100 \mathrm{~m}$ depth layer. Primary production data (Alcaraz et al. 1998, Varela et al. 2002) for the different regions of the WAP were extracted from the literature (Table 3), and carbon to nitrogen units were transformed using a Redfield C:N ratio of 100:16 (Goldman \& McCarthy 1978). In general, this supply was low but in the range of previous studies (Atkinson \& Whitehouse 2001). Indeed, using excretion rates from the literature, $3.3 \%$ of the ammonium required to support primary production was regenerated by Antarctic krill in the Bellingshausen Sea. The Antarctic Sound presented unexpected low values owing to the location of krill below the top $100 \mathrm{~m}$ layer (Fig. 2C) and an assumption of no migration to the upper layers. By contrast, copepod ammonium excretion showed, in this area, relatively high values compared with other taxa (Table 3 ). Unlike other areas, salps were present only in the Bransfield Strait and contributed close to $75 \%$ of the total zooplankton excretion, showing a rather low contribution to primary production (Table 3 ). Hence, the contribution of the zooplankton community to phytoplankton nitrogen demand depends on the spatial and vertical distribution of the main taxonomic groups, and this contribution generally represents a minor role in the regeneration of reduced nitrogen (Alcaraz et al. 1998).

The length of incubation is, therefore, an important factor for the estimation of metabolic rates. Standard rates normally used to estimate the contribution of zooplankton to primary production gives rise to rather low values. The excretion rates obtained by our experimental procedure for krill, which were close to field rates, provided a large difference in the Bellingshausen Sea when rates of fed animals were used (see Table 3). This suggests that Antarctic krill play an important role in regenerating ammonium since they may provide up to $33 \%$ of ammonium required by primary producers, at least in the open waters of the Bellingshausen Sea. Moreover, krill biomass was particularly low (1.7 to $13.4 \mathrm{mg} \mathrm{DW} \mathrm{m}^{-3}$ ), and it is known from acoustic surveys, that small nets such as the one used in this study underestimate the true biomass (Watkins et al. 2000). A much higher biomass is normally found in the region (Siegel \& Loeb 1995, Siegel 2000, Shreeve et al. 2002, Quetin \& Ross 2003, Hewitt et al. 2004, Siegel et al. 2004) and should raise the true ammonium concentration to much higher levels. As stated by Huntley \& Lopez (1992), accurate measurements of biomass seem to be a major outstanding issue when estimating the production of zooplankton communities. Krill excretion, particularly along the western Antarctic Peninsula, should be evaluated by taking into account its variability in biomass, which should be much higher than our excretion rate measurements. Also, krill

Table 3. Primary production, ammonium regenerated by dominant groups of zooplankton and contribution of krill to ammonium demand in the different areas along the western Antarctic Peninsula. Biomass values are mean \pm SD where appropriate

\begin{tabular}{|c|c|c|c|}
\hline Variable & $\begin{array}{c}\text { Bellingshausen } \\
\text { Sea }\end{array}$ & $\begin{array}{l}\text { Bransfield } \\
\text { Strait }\end{array}$ & $\begin{array}{l}\text { Antarctic } \\
\text { Sound }\end{array}$ \\
\hline Zooplankton biomass in the top $100 \mathrm{~m}$ layer $\left(\mathrm{g} \mathrm{DW} \mathrm{\textrm {m } ^ { - 2 } )}\right.$ & $2.19 \pm 1.81$ & $1.70 \pm 2.20$ & 0.80 \\
\hline Primary production $\left(\mathrm{mmol} \mathrm{N} \mathrm{m}^{-2} \mathrm{~d}^{-1}\right)$ & $2.67-6.67^{\mathrm{a}}$ & $6.67-13.33^{\mathrm{a}}$ & $8.95^{\mathrm{b}}$ \\
\hline Ammonium regenerated by salps in the top $100 \mathrm{~m}$ layer $\left(\mathrm{mmol} \mathrm{m}^{-2} \mathrm{~d}^{-1}\right)^{\mathrm{c}}$ & 0 & 0.16 & 0 \\
\hline Ammonium regenerated by copepods in the top $100 \mathrm{~m}$ layer $\left(\mathrm{mmol} \mathrm{m}^{-2} \mathrm{~d}^{-1}\right)^{\mathrm{d}}$ & 0.002 & 0.028 & 0.058 \\
\hline Ammonium regenerated by krill in the top $100 \mathrm{~m}$ layer $\left(\mathrm{mmol} \mathrm{m}^{-2} \mathrm{~d}^{-1}\right)^{\mathrm{e}}$ & 0.089 & 0.025 & 0.012 \\
\hline Percent contribution of krill to ammonium demand ${ }^{\mathrm{e}}$ & $1.13-3.32$ & $0.19-0.38$ & 0.13 \\
\hline Percent contribution of copepods to ammonium demand & $0.03-0.08$ & $0.21-0.43$ & 0.64 \\
\hline Percent contribution of salps to ammonium demand & 0 & $1.24-2.47$ & 0 \\
\hline Ammonium regenerated by krill in the top $100 \mathrm{~m}$ layer $\left(\mathrm{mmol} \mathrm{m}{ }^{-2} \mathrm{~d}^{-1}\right)^{\mathrm{f}}$ & 0.89 & 0.15 & 0.012 \\
\hline Percent contribution of krill to ammonium demand ${ }^{\mathrm{f}}$ & $13.30-33.25$ & $1.09-2.18$ & 0.13 \\
\hline
\end{tabular}


swarms of $>1000$ ind. $\mathrm{m}^{-3}$, extending to $>1 \mathrm{~km}^{2}$ and swimming over distances of $100 \mathrm{~km}$ (Kils 1979) in a relatively short period (Kanda et al. 1982), were previously observed close to the Antarctic Peninsula (Nicol 2003). Despite the interannual biomass variability, krill swarms may represent an overwhelming source of regenerated nitrogen through grazing and excretion (Hirche 1983, Huntley \& Nordhausen 1995) since high nitrogen concentrations are found within krill aggregations (Johnson et al. 1984, as cited in Priddle et al. 1997). Thus, the high quantities of iron (Tovar-Sánchez et al. 2007) and ammonium released by the krill community as observed in the present work provide optimal conditions for phytoplankton growth (Timmermans et al. 1994, Priddle et al. 1997, Whitehouse et al. 1999). The observation of higher excretion rates than those previously estimated indicate that krill play a much greater role in ammonium production in the Antarctic Peninsula than hitherto considered. These results suggest that high krill biomass fuels regenerated primary production in Antarctic waters.

Acknowledgements. This research was financially supported by project ICEPOS (Ren 2002-04165) from the Spanish Commission for Science and Technology (CICYT). We acknowledge the assistance at sea by the members of the Unidad de Tecnología Marina and the crew of the RV 'Hespérides'. The authors are indebted to R. Martínez and S. Putzeys for their help during the cruise and to J. C. Gómez Fernández for advice.

\section{LITERATURE CITED}

Agustí S, Duarte CM, Llabrés M, Agawin NSR, Kennedy H (2009) Response of coastal Antarctic phytoplankton to solar radiation and ammonium manipulation: an in situ mesocosm experiment. J Geophys Res 114:G01009. doi: 10.1029/2008JG000753

Alcaraz M, Saiz E, Fernandez JA, Trepa I, Figueiras F, Calbet A, Bautista B (1998) Antarctic zooplankton metabolism: carbon requirements and ammonium excretion of salps and crustacean zooplankton in the vicinity of the Bransfield Strait during January 1994. J Mar Syst 17: 347-359

> Atkinson A, Snÿder R (1997) Krill-copepod interactions at South Georgia, Antarctica, I. Omnivory by Euphausia superba. Mar Ecol Prog Ser 160:63-76

Atkinson A, Whitehouse MJ (2001) Ammonium regeneration by antarctic mesozooplankton: an allometric approach. Mar Biol 139:301-311

Atkinson A, Ward P, Hill A, Brierly AS, Cripps GC (1999) Krill-copepod interactions at South Georgia, Antarctica, II. Euphausia superba as a major control on copepod abundance. Mar Ecol Prog Ser 176:63-79

> Atkinson A, Whitehouse MJ (2000) Ammonium excretion by Antarctic krill Euphausia superba at South Georgia. Limnol Oceanogr 45:55-63
Atkinson A, Whitehouse MJ, Priddle J, Cripps GC, Ward P, Brandon MA (2001) South Georgia, Antarctica: a productive, cold water, pelagic ecosystem. Mar Ecol Prog Ser 216:279-308

> Båmstedt U (1985) Seasonal excretion rates of macrozooplankton from the Swedish west coast. Limnol Oceanogr 30:607-617

Biggs DC (1977) Respiration and ammonium excretion by open ocean gelatinous zooplankton. Limnol Oceanogr 22:108-117

Bode A, Castro CG, Doval MD, Varela M (2002) New and regenerated production and ammonium regeneration in the western Bransfield Strait region (Antarctica) during phytoplankton bloom conditions in summer. Deep-Sea Res II 49:787-804

Boyd PW, Watson AJ, Law CS, Abraham ER and others (2000) A mesoscale phytoplankton bloom in the polar Southern Ocean stimulated by iron fertilization. Nature 407:695-702

Broughton EA, Lough RG (2006) A direct comparison of $1-\mathrm{m}^{2}$ MOCNESS and Video Plankton Recorder zooplankton abundance estimates: possible applications for augmenting net sampling with video systems. Deep-Sea Res II 53:2789-2807

> Burd BJ, Thomson RE (2012) Estimating zooplankton biomass distribution in the water column near the Endeavour Segment of Juan de Fuca Ridge using acoustic backscatter and concurrently towed nets. Oceanography 25:269-276

Chekunova VI, Rynkova TI (1974) Energy requirements of the Antarctic crustacean Euphausia superba Dana. Oceanology 14:434-440

> Clarke A, Prothero-Thomas E (1997) The influence of feeding on oxygen consumption and nitrogen excretion in the Antarctic nemertean Parborlasia corrugatus. Physiol Zool 70:639-649

- Conover RJ, Gustavson KR (1999) Sources of urea in arctic seas: zooplankton metabolism. Mar Ecol Prog Ser 179:41-54

Daly KL, Macaulay MC (1991) Influence of physical and biological mesoscale dynamics on the seasonal distribution and behavior of Euphausia superba in the Antarctic marginal ice zone. Mar Ecol Prog Ser 79:37-66

$>$ De Baar HJW, de Jong JTM, Bakker DCE, Löscher BM, Veth C, Bathmann U, Smetacek V (1995) Importance of iron for plankton blooms and carbon dioxide drawdown in the Southern Ocean. Nature 373:412-415

> Dortch Q (1990) The interaction between ammonium and nitrate uptake in phytoplankton. Mar Ecol Prog Ser 61: 183-201

> Dugdale RC, Goering JJ (1967) Uptake of new and regenerated forms of nitrogen in primary productivity. Limnol Oceanogr 12:196-206

Dugdale RC (1976) Nutrient cycles. In: Cushing DH, Walsh JJ (eds) The ecology of the sea. Blackwell Scientific Publications, Oxford, p 141-172

- Garibotti IA, Vernet M, Ferrario ME, Smith RC, Ross RM, Quetin LB (2003) Phytoplankton spatial distribution patterns along the western Antarctic Peninsula (Southern Ocean). Mar Ecol Prog Ser 261:21-39

George RY, Fields JR (1984) Ammonia excretion in the Antarctic krill Euphausia superba in relation to starvation and ontogenetic stages. J Crustac Biol 4:263-272

Goldman JC, McCarthy JJ (1978) Steady state growth and ammonium uptake of a fast growing marine diatom. Limnol Oceanogr 23:695-703 
Granéli E, Granéli W, Rabbani MM, Daubjerg N, Franz G, Cuzin Roudy J, Alder VA (1993) The influence of copepod and krill grazing on the species composition of phytoplankton communities from the Scotia-Weddell. An experimental approach. Polar Biol 13:201-213

Grosjean P, Picheral M, Warembourg C, Gorsky G (2004) Enumeration, measurement, and identification of net zooplankton samples using the ZOOSCAN digital imaging system. ICES J Mar Sci 61:518-525

Hamner WM, Hamner PP (2000) Behaviour of Antarctic krill (Euphausia superba): schooling, foraging, and antipredatory behaviour. Can J Fish Aquat Sci 57(Suppl S3): 192-202

Head EJ, Bedo A, Harris LR (1988) Grazing, defecation and excretion rates of copepods from inter-island channels of the Canadian Arctic archipelago. Mar Biol 99:333-340

Hernández-León S, Ikeda T (2005) A global assessment of mesozooplankton respiration in the ocean. J Plankton Res 27:153-158

> Hernández-León S, Torres S, Gómez M, Montero I, Almeida C (1999) Biomass and metabolism of zooplankton in the Bransfield Strait (Antarctic Peninsula) during austral spring. Polar Biol 21:214-219

Hernández-León S, Almeida C, Portillo-Hahnefeld A, Bécognée P, Moreno I (2001) Diel feeding behaviour of krill in the Gerlache Strait, Antarctica. Mar Ecol Prog Ser 223: $235-242$

> Hernández-León S, Montero I, Almeida C, Portillo-Hahnefeld A, Bruce-Lauli E (2008) Mesozooplankton biomass and indices of grazing and metabolic activity in Antarctic waters. Polar Biol 31:1373-1382

Hewitt RP, Kim S, Naganobu M, Gutierrez M and others (2004) Variation in the biomass density and demography of Antarctic krill in the vicinity of the South Shetland Islands during the 1999/2000 austral summer. Deep-Sea Res II 51:1411-1419

> Hirche HJ (1983) Excretion and respiration of the Antarctic krill Euphausia superba. Polar Biol 1:205-209

Holm-Hansen O, Kahru M, Hewes CD (2005) Deep chlorophyll a maxima (DCMs) in pelagic Antarctic waters. II. Relation to bathymetric features and dissolved iron concentrations. Mar Ecol Prog Ser 297:71-81

Huntley ME, Lopez MDG (1992) Temperature-dependent production of marine copepods: a global synthesis. Am Nat 140:201-242

> Huntley ME, Nordhausen W (1995) Ammonium cycling by Antarctic zooplankton in winter. Mar Biol 121:457-467

> Ikeda T, Dixon P (1984) The influence of feeding on the metabolic activity of Antarctic krill (Euphausia superba Dana). Polar Biol 3:1-9

> Ikeda T, Mitchell AW (1982) Oxygen uptake, ammonia excretion and phosphate excretion by krill and other Antarctic zooplankton in relation to their body size and chemical composition. Mar Biol 71:283-298

> Ikeda T, Skjoldal HR (1980) The effect of laboratory conditions on the extrapolation of experimental measurements to the ecology of marine zooplankton. Mar Biol 58: 285-293

Ikeda T, Torres JJ, Hernández-León S, Geiger SP (2000) Metabolism. In: Harris RP, Wiebe $\mathrm{PH}$, Lenz J, Skjoldal HR, Huntley M (eds) ICES zooplankton methodology manual. Academic Press, London, p 455-532

Ikeda T, Kanno Y, Ozaki K, Shinada A (2001) Metabolic rates of epipelagic marine copepods as a function of body mass and temperature. Mar Biol 139:587-596
Johnson MA, Macaulay MC, Biggs JDC (1984) Respiration and excretion within a mass aggregation of Euphausia superba: implications for krill distribution. J Crustac Biol 4:174-184

Kalinowski J (1978) Vertical migration of krill in the region of South Georgia, February-March, 1976. Pol Arch Hydrobiol 25:573-583

Kanda K, Takagi K, Seki Y (1982) Movement of the larger swarms of Antarctic krill Euphausia superba off Enderby Land during 1976-77 season. J Tokyo Univ Fish 68: 24-42

> Kerouel R, Aminot A (1997) Fluorometric determination of ammonia in sea and estuarine waters by direct segmented flow analysis. Mar Chem 57:265-275

Kils U (1979) Swimming speed and escape capacity of Antarctic krill, Euphausia superba. Meeresforschung 27: 264-266

Koike I, Holm-Hansen O, Biggs DC (1986) Inorganic nitrogen metabolism by Antarctic phytoplankton with special reference to ammonium cycling. Mar Ecol Prog Ser 30: 105-116

- Le Borgne R (1979) Influence of duration of incubation on zooplankton respiration and excretion results. J Exp Mar Biol Ecol 37:127-137

Lehette P, Hernández-León S (2009) Zooplankton biomass estimation from digitized images: a comparison between subtropical and Antarctic organisms. Limnol Oceanogr Methods 7:304-308

Lehette P, Hernández-León S (2010) Carbon dioxide production rates of marine epipelagic copepods in subtropical waters during the late winter bloom. J Exp Mar Biol Ecol 385:38-43

Martin JH, Fitzwater SE (1988) Iron deficiency limits phytoplankton growth in the north-east Pacific subarctic. Nature 331:341-343

> Martin JH, Gordon RM, Fitzwater S (1990) Iron in Antarctic waters. Nature 345:156-158

> McCarthy JJ, Taylor RW, Taft JL (1977) Nitrogenous nutrition of the plankton in the Chesapeake Bay. I. Nutrient availability and nitrogen. Limnol Oceanogr 22:996-1011

> Meyer B, Atkinson A, Stübing D, Oettl B, Hagen W, Schmidt K (2002) Feeding and energy budgets of Antarctic krill Euphausia superba at the onset of winter-I. Furcilia III larvae. Limnol Oceanogr 47:943-952

> Miller C, Glibert P (1998) Nitrogen excretion by the calanoid copepod Acartia tonsa: results of mesocosm experiments. J Plankton Res 20:1767-1780

Moore JK, Abbott MR (2000) Phytoplankton chlorophyll distributions and primary production in the Southern Ocean. J Geophys Res 105(C12): 28709-28722

Morris DJ, Ward P, Clarke A (1983) Some aspects of feeding in the Antarctic krill, Euphausia superba. Polar Biol 2: 21-26

Nicol S (2003) Living krill, zooplankton and experimental investigations. Mar Freshw Behav Physiol 36:191-205

Nordhausen W (1994) Winter abundance and distribution of Euphausia superba, E. Crystallorophias, and Thysanoessa macrura in Gerlache Strait and Cristal Sound, Antarctica. Mar Ecol Prog Ser 109:131-142

O'Brien DP (1987) Direct observations of the behavior of Euphausia superba and Euphausia crystallorophias (Crustacea: Euphausiacea) under pack ice during the Antarctic spring of 1985. J Crustac Biol 7:437-448

Omori M, Ikeda T (1984) Methods in marine zooplankton ecology. John Wiley, New York, NY 
Park MG, Yang SR, Kang SH, Chung KH, Shim JH (1999) Phytoplankton biomass and primary production in the marginal ice zone of the northwestern Weddell Sea during austral summer. Polar Biol 21:251-261

Priddle J, Leakey R, Symon C, Whitehouse M, Robins D, Cripps G, Murphy E, Owens N (1995) Nutrient cycling by Antarctic marine microbial plankton. Mar Ecol Prog Ser 116:181-198

Priddle J, Whitehouse MJ, Atkinson A, Brierley AS, Murphy EJ (1997) Diurnal changes in near-surface layer ammonium concentration-interplay between zooplankton and phytoplankton. J Plankton Res 19:1305-1330

Priddle J, Whitehouse MJ, Ward P, Shreeve RS and others (2003) Biogeochemistry of a Southern Ocean plankton ecosystem: Using natural variability in community composition to study the role of metazooplankton in carbon and nitrogen cycles. J Geophys Res 108 (C4): art no 8082

Quetin LB, Ross RM (2003) Episodic recruitment in Antarctic krill Euphausia superba in the Palmer LTER study region. Mar Ecol Prog Ser 259:185-200

Reay DS, Nedwell DB, Priddle J, Ellis-Evans JC (1999) Temperature dependence of inorganic nitrogen uptake: reduced affinity for nitrate at suboptimal temperatures in both algae and bacteria. Appl Environ Microbiol 65: 2577-2584

Reay DS, Priddle J, Nedwell DB, Whitehouse MJ, EllisEvans JC, Deubert C, Connelly DP (2001) Regulation by low temperature of phytoplankton growth and nutrient uptake in the Southern Ocean. Mar Ecol Prog Ser 219: 51-64

Ritz DA (2000) Is social aggregation in aquatic crustaceans a strategy to conserve energy? Can J Fish Aquat Sci 57: $59-67$

Ritz DA, Foster EG, Swadling KM (2001) Benefits of swarming: mysids in larger swarms save energy. J Mar Biol Assoc UK 81:543-544

Ritz DA, Cromer L, Swadling KM, Nicol S, Osborn J (2003) Heart rate as a measure of stress in Antarctic krill, Euphausia superba. J Mar Biol Assoc UK 83:329-330

Sameoto DD (1976) Respiration rates, energy budgets and molting frequencies of three species of euphausiids found in the Gulf of St. Lawrence. J Fish Res Board Can 33:2568-2576

Sameoto DD, Jaroszynski LO, Fraser WB (1980) BIONESS, a new design in multiple net zooplankton samplers. Can J Fish Aquat Sci 37:722-724

Satomi M, Pomeroy LR (1965) Respiration and phosphorus excretion in some marine populations. Ecology 46: 877-881

Shreeve RS, Ward P, Whitehouse MJ (2002) Copepod growth and development around South Georgia: relationships with temperature, food and krill. Mar Ecol Prog Ser 233:169-183

Siegel V (1988) A concept of seasonal variation of krill (Euphausia superba) distribution and abundance west of

Editorial responsibility: Antonio Bode, A Coruña, Spain the Antarctic Peninsula. In: Sahrhage D (ed) Antarctic Ocean and resources variability. Springer, Berlin, p 219-230

> Siegel V (2000) Krill (Euphausiacea) demography and variability in abundance and distribution. Can J Fish Aquat Sci 57(Suppl 3):151-167

Siegel V (2005) Distribution and population dynamics of Euphausia superba: summary of recent findings. Polar Biol 29:1-22

> Siegel V, Loeb V (1995) Recruitment of Antarctic krill Euphausia superba and possible causes for its variability. Mar Ecol Prog Ser 123:45-63

Siegel V, Kawaguchi S, Ward P, Litvinov F, Sushin V, Loeb V, Watkins J (2004) Krill demography and large-scale distribution in the southwest Atlantic during January/ February 2000. Deep-Sea Res II 51:1253-1273

> Sullivan CW, Arrigo KR, McClain CR, Comiso JC, Firestone J (1993) Distributions of phytoplankton blooms in the Southern Ocean. Science 262:1832-1837

> Timmermans KR, Stolte W, de Baar HJW (1994) Iron-mediated effects on nitrate reductase in marine phytoplankton. Mar Biol 121:389-396

Tomo AP (1983) Study on the diurnal migration of Euphausia superba and the formation of shoals. Ber Polarforsch 4:191-195

Tovar-Sanchez A, Duarte CM, Hernández-León S, SanudoWilhelmy SA (2007) Krill as a central node for iron cycling in the Southern Ocean. Geophys Res Lett 34: L11601 doi: 10.1029/2006GL029096

> Varela M, Fernández E, Serret P (2002) Size-fractionated phytoplankton biomass and primary production in the Gearlache and south Bransfield Straits (Antarctic Peninsula) in the austral summer 1995-1996. Deep-Sea Res II 49:749-768

Watkins J, Macaulay M, Everson I (2000) Sampling krill. In: Everson I (ed) Krill biology, ecology and fisheries. Blackwell Science, London, p 8-39

$>$ Webb KL, Johannes RE (1967) Studies of the release of dissolved free amino acids by marine zooplankton. Limnol Oceanogr 12:376-382

- Whitehouse MJ, Priddle J, Brandon MA, Swanson C (1999) A comparison of chlorophyll/nutrient dynamics at two survey sites near South Georgia, and the potential role of planktonic nitrogen recycled by land-based predators. Limnol Oceanogr 44:1498-1508

> Whitehouse MJ, Atkison A, Rees AP (2011) Close coupling between ammonium uptake by phytoplankton and excretion by Antarctic krill, Euphausia superba. DeepSea Res I 58:725-732

Zhou M, Dorland RD (2004) Aggregation and vertical migration behavior of Euphausia superba. Deep-Sea Res II 51: 2119-2137

> Zhou M, Huntley ME (1996) The principle of biological attraction, demonstrated by the bio-continuum theory of zooplankton patch dynamics. J Mar Res 54:1017-1037

Submitted: August 24, 2011; Accepted: April 4, 2012

Proofs received from author(s): July 7, 2012 